\title{
PENERAPAN MODEL KOOPERATIF TIPE NUMBERED HEAD TOGETHER UNTUK MENINGKATKAN HASIL BELAJAR MATEMATIKA SISWA PADA SISTEM PERSAMAAN LINEAR DUA PEUBAH DI MTS RAUDHATUL HASANAH MEDAN
}

\author{
Solahuddin Al'Ayyubi Dalimunthe \\ FMIPA Unimed Medan \\ Email: solahuddin_yubie@yahoo.com \\ E. Elvis Napitupulu \\ Dosen Matematika Unimed Medan \\ Email: elvisnapit@gmail;
}

\begin{abstract}
The purpose of this study was to determine the increase in student learning outcomes on the subject of the system of linear equationswith two variables cooperative learning Numbered Head Together. Subjects in this study were class VIII-2 MTs Raudhatul Hasanah many as 31 people. The object of this research is the application of the cooperative model Numbered Head Together. The research instrument used by observation and tests. This type of research is a classroom action research. Before giving action, first given a diagnostic test to determine the ability and determination of the initial group of students based on ability level. The data provided in the form of shaped achievment test descipsion given twice at the end of each cycle. In this study the use of worksheets intended as teachingn tool to facilitate teaching and learning in cooperative groups. From the analysis of the data after a given action I (cycle I) obtained 23 out of 31 student $(74,19 \%)$ reached mastery learning and 8 out of 31 students $(25,80 \%)$ has not reached mastery learning with an average grade 68,70. In this cycle of learning completeness in classical yet achieved. From the analysis of the data after a given action II (cycle II) obtained 27 out of 31 students $(87,10 \%)$ reached mastery learning, and 4 out 31 students $(12,90 \%)$ has not reached mastery learning with an average grade 77, 09. In this cycle of learning completeness classically been reached. This means that an increase in student learning outcomes from cyle I to cycle II. Thus the implementation of cooperative learning model Numbered Head Together can improve student learning outcomes on the subject of the system of linear equations in two variables of class VIII MTs Raudhatul Hasanah.
\end{abstract}

Keywords : Cooperative, Numbered Head Together, Raudhatul Hasanah.

\section{PENDAHULUAN}

\section{Latar Belakang}

Pendidikan merupakan kebutuhan setiap manusia sepanjang hidupnya. Tanpa adanya pendidikan manusia akan sulit berkembang bahkan akan terbelakang. Salah satu masalah yang dihadapi dunia pendidikan di Indonesia adalah masalah lemahnya proses pembelajaran. Berbagai upaya untuk meningkatkan mutu pendidikan telah dan terus dilakukan. Namun, indikator kearah mutu pendidikan belum menunjukkan peningkatan yang signifikan. Salah satu cara untuk meningkatkan pendidikan di

Solahuddin Al'Ayyubi Dalimunthe, E. Elvis Napitupulu. 2015. Penerapan Model Kooperatif Tipe Numbered Head Together untuk Meningkatkan Hasil Belajar Matematika Siswa pada Sistem Persamaan Linear Dua Peubah di MTS Raudhatul Hasanah Medan. Inspiratif. Vol. 1 No. 1, hal. 63-74 
Indonesia adalah dengan melakukan perbaikan dalam proses pembelajaran, maka perlu diadakan upaya dalam perbaikan pembelajaran seiring dengan perkembangan zaman yang menuntut siswa untuk berwawasan luas.

Pendidikan yang diberikan di sekolah dasar, sekolah lanjutan maupun di sekolah menengah meliputi beberapa mata pelajaran, salah satunya adalah mata pelajaran matematika. Matematika merupakan salah satu cabang ilmu pengetahuan yang selalu digunakan dalam segala segi kehidupan, dan juga menopang cabang pengetahuan yang lain, sehingga matematika sering dikatakan sebagai queen and service of science (ratu dan pelayan ilmu pengetahuan). Matematika berkembang seiring dengan peradaban manusia. Sejarah ilmu pengetahuan menempatkan matematika pada bagian puncak hierarki ilmu pengetahuan. Peletakan demikian ini menimbulkan mitos bahwa matematika adalah penentu tingkat intelektualitas seseorang (Masykur, 2008:66).

Matematika adalah ilmu universal yang mendasari perkembangan teknologi modern, mempunyai peranan penting dalam berbagai disiplin ilmu dan memajukan daya pikir manusia. Untuk menguasai dan menciptakan teknologi di masa depan diperlukan penguasaan matematika yang kuat sejak dini. Seperti yang diungkapkan oleh Hudojo (1988:1) bahwa matematika berfungsi mendasari perkembangan ilmu pengetahuan dan teknologi, merupakan pengetahuan yang esensial sebagai dasar untuk bekerja seumur hidup dalam abad globalisasi.

Matematika dipelajari oleh semua siswa dari tingkatan SD hingga SMA dan bahkan sampai Perguruan Tinggi. Ada banyak alasan perlunya siswa belajar matematika menurut Cornelius (Abdurrahman, 2009 :253) karena matematika merupakan:(1) sarana berpikir yang jelas dan logis, (2) sarana untuk memecahkan masalah kehidupan sehari-hari, (3) sarana mengenal pola-pola hubungan dan generalisasi pengalaman, (4) sarana untuk mengembangkan kreativitas, dan (5) sarana untuk meningkatkan kesadaran terhadap perkembangan budaya.

Pendidikan matematika berperan penting bagi setiap individu karena dengan matematika setiap individu dapat meningkatkan kemampuan bernalar, berpikir kritis, logis, sistematis dan kreatif. Namun pada kenyataannya sedikit sekali orang yang menyukai matematika. Banyak orang beranggapan bahwa matematika adalah mata pelajaran yang sangat sulit dan menakutkan dibandingkan dengan mata pelajaran lain.Djamarah (1994:15) mengatakan bahwa

Penyebab siswa takut matematika diantaranya mencakup penekanan yang berlebihan pada penghafalan semata, penekanan pada kecepatan berhitung, pengajaran otoriter, kurangnya variasi pada proses belajar mengajar matematika, serta penekanan berlebihan pada prestasi individu. Karena itu untuk mengatasi masalah ini, peranan guru sangatlah penting. Sebab kesulitan dan ketakutan siswa dalam belajar matematika akan menyebabkan rendahnya hasil belajar matematika siswa.

Belajar matematika tidak sama dengan belajar sejarah, metode menghafal tidak cukup karena matematika bukanlah ilmu hafalan. Jika ingin berhasil mengerjakan soal-soal matematika maka harus banyak berlatih dan memahami rumus-rumusnya. Dalam prakteknya di sekolah, keaktifan siswa dalam mengerjakan soal-soal latihan pada proses pembelajaran masih kurang, seperti siswa tidak berani untuk mengerjakan soal di depan kelas dan siswa jarang mengajukan pertanyaan. Kebanyakan siswa cenderung hanya sekedar menghapal konsep yang ada dan meniru langkah-langkah penyelesaian yang diberikan oleh guru, ketika mereka ditanya apakah mereka mengerti dengan konsep yang dimaksud, maka jawaban mereka 
adalah tidak, mereka mengakui bahwa hanya hapal saja.

Salah satu materi matematika yang dianggap susah oleh siswa adalah sistem persamaan linear dua variabel.Materi ini merupakan materi lanjutan materi dari sistem persamaan linear satu variabel yang telah dipelajari di kelas VII SMP. Akan tetapi masih banyak siswa yang mengalami kesulitan dalam mempelajari, memahami dan menyelesaikan soal-soal sistem persamaan linear dua variabel.

Berdasarkan tes diagnostik (tanggal 14 Agustus 2014) di Madrasah Tsanawiyah Raudhatul Hasanah masih banyak siswa lemah dalam pelajaran matematika. Ini dapat dilihat dari pencapaian nilai rata-rata hasil belajar tes diagnostic matematika siswa pada materi pokok sistem persamaan linear satu variabeldi kelas VIII ${ }_{2} \mathrm{MTs}$ Raudhatul Hasanah Tahun Ajaran 2014/2015adalah 44,51 dari31 orang siswa dan persentase ketuntasan klasikal 25,80\% dengan KKM (KriteriaKetuntasan Minimum) adalah65.

Tes diagnostik ini adalah pemberian soal yang berhubungan dengan sistem persamaan linear satu variabel dalam bentuk soal uraian. Tes diagnostik ini diberikan agar siswa mengingat kembali materi sistem persamaan linear satu variabel sehingga dapat melanjutkan pada materi sistem persamaan linear dua variabel.

Banyaknya siswa yang lemah dalam pelajaran matematika di kelas $\mathrm{VIII}_{2} \mathrm{MTS}$ Raudhatul Hasanah sangat memprihatinkan. Jika masalah ini dibiarkan terus-menerus, maka siswa kelas VIII akan mengalami kesulitan dalam pokok bahasan sistem persamaan linear dua variabel.

Upaya peningkatan mutu pendidikanharuslah dilakukan dengan menggunakan seluruh komponen dalam pendidikaN. Kesulitan siswa dalam mempelajari Matematika harus menjadi tanggungjawab guru sebagai aktor utama dalam proses belajar mengajar.Muhammad (dalam terintregasi Matematika Buku 3, 2005: 1) menyatakan bahwa:Tenaga kependidikan, terutama guru matematika; di samping tenaga kependidikan lainnya seperti kepala sekolah dan pustakawan, adalah merupakan faktor yang sangat menentukan mutu pendidikan matematika.

Tidak dapat dipungkiri bahwa sebagian guru masih menggunakan paradigma lama dalam mengajar.Dalam pembelajaran matematika, biasanya guru memulai sajian dengan mengajar teori/ definisi/ teorema, diberikan contoh, dan terakhir diberikan latihan soal-soal.

Pembelajaran yang selama ini digunakan oleh guru matematika di MTs Raudhatul Hasanahadalah metode ceramah. Artinya, guru masih menggunakan pembelajaran yang guru lebih berperan aktif dibandingkan siswa, sehingga masih ada kesulitan-kesulitan yang dialami siswa selama belajar Sistem Persamaan Dua Peubah dengan menggunakan pembelajaran tersebut. Untuk mencapai pembelajaran yang optimal, proses pembelajaran harus dibuat lebih menarik dan lebih mudah dimengerti sehingga dapat meningkatkan hasil belajar siswa. Dalam hal ini guru dapat menerapkan pembelajaran yang lebih baik dari yang sebelumnya. Model pembelajaran kooperatif dapat dijadikan alternatif yang diharapkan dapat meningkatkan hasil belajar siswa.

Pembelajaran kooperatif adalah model pembelajaran yang banyak digunakan dalam penerapan kurikulum tingkat satuan pendidikan. Walaupun prinsip dasar pembelajaran kooperatif tidak berubah, namun terdapat beberapa tipe dari model tersebut. Trianto (2009:62) menyatakan bahwa:

Terdapat enam fase sebagai sintaks dalam pembelajaran kooperatif, Menyampaikan tujuan dan memotivasi siswa, (2) Menyajikan informasi, (3) Mengorganisasikan siswa ke dalam kelompok kooperatif, (4) Membimbing kelompok bekerja dan belajar, (5) Evaluasi dan (6) Memberikan penghargaan. 
Salah satu tipe dalam pembelajaran kooperatif yang dianggap peneliti dapat memotivasi siswa dalam peran aktif dalam proses belajar mengajar adalah Model Pembelajaran Kooperatif Tipe Numbered Heads Together (NHT.)

Model pembelajaran kooperatif tipe NHT merupakan salah satu tipe pembelajaran kooperatif yang menekankan pada struktur khusus yang dirancang untuk mempengaruhi pola interaksi siswa dan memiliki tujuan untuk meningkatkan penguasaan akademik, meningkatkan kinerja siswa dalam tugas-tugas akademik, agar siswa dapat menerima temantemannya yang mempunyai berbagai latar belakang, dan untuk mengembangkan keterampilan siswa. Keterampilan yang dimaksud antara lain berbagai tugas, aktif bertanya, menghargai pendapat orang lain, mau menjelaskan ide atau pendapat, bekerja dalam kelompok dan sebagainya.

Dengan melihat fenomena tersebut, peneliti bersama guru bermaksud mengadakan kerjasama dalam upaya memberikan solusi dengan menerapkan model pembelajaran kooperatif tipe Numbered Heads Together (NHT) dalam menyelesaikan soal persamaan linear satu variabel.Model pembelajaran ini sangat cocok diterapkan pada pembelajaran matematika karena dalam mempelajari matematika, tidak cukup hanya dengan mengetahui dan menghafalkan konsepkonsep matematika tetapi juga dibutuhkan suatu pemahaman serta kemampuan menyelesaikan persoalan matematika dengan baik dan benar sehingga diharapkan dapat meningkatkan hasil belajar siswa.

Dari uraian di atas sebagai upaya meningkatkan hasil belajar siswa di MTS Raudhatul Hasanah, maka peneliti bersama guru tertarik menerapkan model pembelajaran kooperatif tipe Numbered Heads Together(NHT) guna meningkatkanhasil belajar siswa melalui suatu penelitian yang berjudul:

"Penerapan Model Pembelajaran Kooperatif Numbered Head Togetheruntuk
Meningkatkan Hasil Belajar Sistem Persamaan Linear Dua Peubah di kelas VIII MTS Raudhatul Hasanah.

\section{METODE PENELITIAN}

\section{Tempat dan Waktu Penelitian}

Penelitian ini dilakukan di kelas VIII-2 MTS Raudhatul Hasanah yang beralamatkan di jalan Jamin Ginting km 11 Medan. Dan penelitian ini dilaksanakan di semester ganjil di kelas $\mathrm{VIII}_{2}$ MTs Raudhatul Hasanah.

\section{Jenis Penelitian}

Jenis penelitian yang sesuai dengan permasalahan tersebut adalah penelitian tindakan kelas (Classroom Action Research) dengan menerapkan Pembelajaran Kooperatif.

\section{Prosedur Penelitian}

\section{SIKLUS I}

\section{Tahap Perencanaan Tindakan I}

Sebelum melaksanakan tindakan, hal-hal yang perlu dipersiapkan yaitu :

a. Menyusun Rencana Pelaksanaan Pembelajaran (RPP)

b. Mempersiapkan sarana pembelajaran

c. Menyusun soal LKSdan tes hasil belajar I

d. Mempersiapkan instrumen penelitian, yaitu : (1) lembar observasi kegiatan guru selama KBM, (2) lembar observasi kegiatan siswa selama KBM.

\section{Tahap Pelaksanaan Tindakan I}

Dalam hal ini, peneliti bertindak sebagai fasilitator dan juga guru yang mengajar di kelas, sedangkan guru mata pelajaran matematika kelas $\mathrm{VIII}_{2} \mathrm{MTs}$ Raudhatul Hasanah sebagai pengamat/observer yang akan memberi masukan selama pembelajaran sedang berlangsung. 


\section{Tahap Observasi I}

Observasidilakukan secara bersamaan pada saat pelaksanaan tindakan pembelajaran. Kegiatan observasi dilakukan untuk melihat perilaku guru dan perilaku siswa selama proses belajar mengajar berlangsung.

\section{Tahap Analisis Data I \\ a. Reduksi Data}

Data yang terkumpul baik melalui tes dan observasi kemudian ditelaah oleh peneliti dan guru. Reduksi data dilakukan setelah data terkumpul.

\section{b. Paparan Data}

Data kesalahan siswa yang telah direduksi disajikan dalam bentuk paparan data kesalahan jawaban siswa.

\section{c. Simpulan Data}

Dalam kegiatan ini ditarik kesimpulan berdasarkan hasil penelitian yang telah dilakukan.

\section{Tahap Refleksi I}

Refleksi merupakan perenungan terhadap tuntas tidaknya pelaksanaan tindakan pada siklus I. Jika siklus I belum mencapai ketuntasan maka:

\section{SIKLUS II}

\section{Alat Pengumpul Data}

Tes

Tes hasil belajar pada penelitian ini terdiri dari soal berupa essay tes.Tes ini digunakan untuk mengukur adanya hasil peningkatan hasil belajar matematika siswa.Tes ini terdiri dari tes hasil belajar I (setelah pemberian tindakan I) dan tes hasil belajar II (setelah pemberian tindakan II).

\section{Observasi}

Observasi yang dilakukan ada dua jenis yaitu observasi terhadap peneliti dan siswa.Observasi dianalisis secara deskriptif dari proses pembelajaran. Proses pembelajaran dikatakan efektif jika pelaksanaan pembelajarannya berjalan dengan baik.

\section{Teknik Analisis Data}

\section{Analisis Tes Hasil Belajar Siswa}

Untuk mengetahui hasil belajar siswa telah meningkat atau tidak dapat dilihat dari hasil tes yang diperoleh pada setiap siklusnya. Menurut Nurkanca (dalam Tambunan, 2011:27) kategori penguasaan siswa adalah sebagai berikut:

Tabel 1. Tingkat penguasaan siswa

\begin{tabular}{|c|c|c|}
\hline No & $\begin{array}{c}\text { Persentase } \\
\text { Penguasaan }\end{array}$ & $\begin{array}{c}\text { Kategori } \\
\text { Penguasaan }\end{array}$ \\
\hline 1 & $90 \%-100 \%$ & Sangat Tinggi \\
2 & $80 \%-89 \%$ & Tinggi \\
3 & $65 \%-79 \%$ & Sedang \\
4 & $55 \%-64 \%$ & Rendah \\
5 & $0 \%-54 \%$ & Sangat Rendah \\
\hline
\end{tabular}

Menurut depdikbud (1994:39) dimana setiap skor masing-masing tes yang diberikan akan dilihat ketuntasannya baik secara perorangan maupun secara klasikal dengan menggunakan rumus sebagai berikut:

a. Ketuntasan hasil belajar perorangan (individual) digunakan rumus:

$$
\begin{aligned}
& \text { PHB } \\
& =\frac{\text { skoryangdiperolehsiswa }}{\text { skormaksimal }} \times 100 \%
\end{aligned}
$$

b. Ketuntasan belajar secara klasikal digunakan rumus:

$$
=\frac{\text { jumlah siswa yang telah tuntas belajar }}{\text { jumlah seluruh siswa }} \times 100 \%
$$

Suatu kelas dikatakan tuntas belajar jika dalam kelas tersebut terdapat $85 \%$ yang telah mencapai PHB $\geq 65 \%$.Pembelajaran dikatakan efektif jika ketuntasan belajar dari hasil belajar telah mencapai ketuntasan individual minimal 65 dan ketuntasan klasikal yang dicapai sebesar $85 \%$

\section{Analisis Hasil Observasi}

Dari hasil observasi yang telah dilakukan selama penelitian, dilakukan penganalisaan dengan menggunakan rumus:

$$
P i=\frac{\text { jumlahseluruhaspekyangdiamat } i}{\text { banyaknyaaspekyangdiamati }}
$$

Adapun pedoman untuk mengetahui keberhasilan proses pembelajaran menurut 
sudjana (2009:78) dapat dilihat dari tabel 3.3 berikut ini:

Tabel 2 Tingkat keberhasilan proses pembelajaran

\begin{tabular}{|c|c|}
\hline Tingkat & Kategori \\
\hline $1,0-1,5$ & Sangat Kurang \\
\hline $1,6-2,5$ & Kurang \\
\hline $2,6-3,5$ & Baik \\
\hline $3,6-4,0$ & Sangat Baik \\
\hline
\end{tabular}

Paparan Data

Kegiatan analisis berupa paparan data adalah sebagai kumpulan data yang terorganisasi sehingga memungkinkan adanya kesimpulan data yang dianalisis untuk mendeskripsikan ketuntasan belajar siswa

\section{Penyimpulan Data}

Adapun Indikator keberhasilan dalam penelitian ini adalah: Ketuntasan belajar klasikal tercapai jika $85 \%$ siswa memperoleh nilai $\geq 65 \%$.

\section{HASIL DAN PEMBAHASAN}

\section{Siklus I}

Berdasarkan tes diagnostik diperoleh bahwa hasil belajar siswa masih rendah. Hal ini dapat dilihat dari tes diagnostik yang diberikan hanya 8 orang dari 31 orang siswa $(25,80 \%)$ yang telah mencapai ketuntasan belajar $(\geq 65 \%)$ sedangkan siswa lainnya $(74,19 \%)$ dikategorikan belum mencapai ketuntasan belajar. Dan rata-rata yang dicapai oleh siswa juga masih rendah yaitu hanya mencapai 44,51. Hasil tes diagnostik ini digunakan sebagai acuan untuk memberikan tindakan dan penyusunan skenario pembelajaran untuk dilaksanakan dengan penerapan model kooperatif tipe Numbered Head Together.

\section{Tahap Perencanaan Tindakan I}
a. Menyusun Rencana Pelaksanaan Pembelajaran (RPP)
b. Mempersiapkan sarana pembelajaran
c. MemberikanLKS dan tes hasil belajar I

d. Mempersiapkan instrumen penelitian, yaitu : (1) lembar observasi kegiatan guru selama KBM, (2) lembar observasi kegiatan siswa selama KBM.

\section{Pelaksanaan Tindakan I}

Kegiatan pembelajaran pada siklus I dilakukan sebanyak 2 kali pertemuan.

Langkah 1 (Menyampaikan tujuan dan memotivasi siswa)

1. Guru menginformasikan tujuan pembelajaran

2. Guru memotivasi siswa

Langkah 2 (Menyajikan Informasi)

1. Guru menjelaskan langkah pembelajaran kooperatif tipe Numbered Head Togeteher

2. Guru mengajarkan materi tentang defenisi SPLDV, penyelesaian SPLDV dengan metode grafik, substitusi dan eliminasi

3. Guru menjelaskan terlebih dahulu tentang variabel, koefisien, dan konstanta. Kemudian menjelaskan cara menyelesaikan SPLDV dengan metode grafik yaitu cara mencari titik potong dari persamaan yang diketahui dan menggambarkan titik potong tersebut (pertemuan I)

4. Guru menjelaskan cara menyelesaikan SPLDV dengan metode substitusi dan eliminasi (pertemuan II)

Langkah 3 (Penomoran/Numbering)

1. Mengelompokkan siswa kedalam kelompok-kelompok belajar yang beranggotakan 3-5 orang dan tiap kelompok heterogen

2. Kepada setiap anggota kelompok diberi nomor 1 sampai 5 sebagai pengganti identitas.

\section{Langkah 4 (Mengajukan Pertanyaan)}

1. Peneliti mengarahkan siswa pada masalah melalui LKS I dan LKS II 
Langkah 5 (Berpikir Bersama/Head Together)

1. Guru mengamati jalannya diskusi kelompok dan mendorong siswa untuk berdialog dan berdiskusi dengan teman dalam satu kelompok.

2. Guru membimbing siswa untuk memberi kemudahan pengerjaan soal, misalnya membantu siswa dalam memahami pertanyaan/soal dalam LKS I dan LKS II sehingga siswa mampu memikirkan cara menyelesaikannya.

\section{Langkah 6 (Pemberian Jawaban)}

1. Membimbing siswa mempresentasikan hasil kerja kelompoknya di depan kelas, dan mengarahkan setiap anggota kelompok harus ambil bagian dalam persentasi.

2. Memotivasi kelompok di luar penyaji untuk menanggapi hasil pekerjaan temannya dan menanyakan jika ada hal yang tidak dipahami dengan persentasi kelompok penyaji serta memotivasi kelompok penyaji untuk dapat menanggapi saran maupun pertanyaan dari kelompok lain.

\section{Langkah 7 (Penghargaan)}

1. Memberikan penilaian terhadap hasil belajar masing-masing kelompok dan memberikan penghargaan kepada kelompok dengan hasil terbaik.

2. Membimbing siswa menyimpulkan pelajaran yang telah dipelajari.

3. Di akhir siklus I, siswa diberikan tes hasil belajar I dari materi yang telah dibahas dan dikerjakan secara individu yang bertujuan untuk mengetahui hasil belajar siswa dan letak kesulitan siswa dalam menyelesaikan tes.

\section{Observasi I}

Observasidilakukan secara bersamaan pada saat pelaksanaan tindakan pembelajaran. Pada tahap ini, guru bidang studi matematika kelas $\mathrm{VIII}_{2}$ MTs Raudhatul Hasanah mengamati perilaku peneliti yang bertindak sebagai guru selama proses belajar-mengajar berlangsung, hasil observasi pada siklus I ini dapat dilihat pada (Lampiran 34).Dan hasil observasi yang dilakukan observer bahwa kemampuan siswa sudah baik dan masih perlu ditingkatkan, hasil observasi pada siklus I ini dapat dilihat pada (Lampiran 36).

\section{Analisis Data I}

Berdasarkan hasil jawaban yang diberikan pada tes hasil belajar I dapat dideskripsikan tingkat ketuntasan belajar dan penguasaan siswa sebagai berikut:

1) Secara keseluruhan dari 31 orang siswa diperoleh 3 orang siswa $(9,68 \%)$ memiliki tingkat penguasaan sangat tinggi, 5 orang siswa $(16,12 \%)$ memiliki tingkat penguasaan tinggi dan 15 orang siswa $(48,38 \%)$ memiliki tingkat penguasaan sedang, 2 orang siswa $(6,45 \%)$ memiliki tingkat penguasaan rendah dan 6 orang siswa $(19,35 \%)$ memiliki tingkat penguasaan sangat rendah. Hasil selengkapnya dapat dilihat dari tabel dibawah ini:

Tabel 3. Tingkat penguasaan siswa pada tes hasil belajar I

\begin{tabular}{|c|c|c|c|c|}
\hline No & $\begin{array}{l}\text { Persentase } \\
\text { Penguasaan }\end{array}$ & $\begin{array}{c}\text { Tingkat } \\
\text { Penguasaan }\end{array}$ & $\begin{array}{c}\text { Banyak } \\
\text { Siswa }\end{array}$ & $\begin{array}{c}\text { Persentase } \\
\text { Jumlah } \\
\text { Siswa }\end{array}$ \\
\hline 1 & $90 \%-100 \%$ & Sangat Tinggi & 3 & $9,68 \%$ \\
\hline 2 & $80 \%-89 \%$ & Tinggi & 5 & $16,12 \%$ \\
\hline 3 & $65 \%-79 \%$ & Sedang & 15 & $48,38 \%$ \\
\hline 4 & $55 \%-64 \%$ & Rendah & 2 & $6,45 \%$ \\
\hline 5 & $0 \%-54 \%$ & Sangat Rendah & 6 & $19,35 \%$ \\
\hline \multicolumn{3}{|c|}{ Jumlah } & 31 & $100 \%$ \\
\hline
\end{tabular}

2) Dari 31 orang siswa diperoleh 23 orang siswa $(74,19 \%)$ telah mencapai tingkat ketuntasan belajar $(\geq 65 \%)$, sedangkan 8 orang siswa $(25,80 \%)$ belum mencapai tingkat ketuntasan belajar $(\leq 65 \%)$. Hasil selengkapnya dapat dilihat dari tabel dibawah ini: 
Tabel 4. Data ketuntasan belajar siswa pada tes hasil belajar I

\begin{tabular}{|c|c|c|c|c|}
\hline No & $\begin{array}{l}\text { Persentase } \\
\text { Ketuntasan }\end{array}$ & $\begin{array}{c}\text { Tingkat } \\
\text { Ketuntasa } \\
n\end{array}$ & $\begin{array}{c}\text { Banyak } \\
\text { Siswa }\end{array}$ & $\begin{array}{c}\text { Persentase } \\
\text { Jumlah } \\
\text { Siswa }\end{array}$ \\
\hline 1 & $<65 \%$ & $\begin{array}{c}\text { Tidak } \\
\text { Tuntas }\end{array}$ & 8 & $25,80 \%$ \\
\hline 2 & $\geq 65 \%$ & Tuntas & 23 & $74,19 \%$ \\
\hline \multicolumn{3}{|c|}{ Jumlah } & 31 & $100 \%$ \\
\hline
\end{tabular}

Berdasarkan data hasil tes belajar I di atas dapat dilihat bahwa hasil belajar siswa meningkat dari sebelumnya. Hal ini dilihat dari nilai rata-rata kelas pada tes awal sebesar 44,51 meningkat menjadi 68,70 pada tes hasil belajar I. Walaupun terjadi peningkatan tetapi tingkat ketuntasan belajar klasikal yang diperoleh belum tercapai.

\section{Siklus II}

Berdasarkan hasil tes hasil belajar I yang dilakukan menunjukkan bahwa siswa banyak mengalami kesulitan dalam menyelesaikan soal-soal yang diberikan. Beberapa gambaran siswa yang ditemukan yaitu:

1. Siswa masih malu bertanya kepada guru.

2. Siswa kurang kondusif dalam diskusi kelompoknya.

3. Siswa masih kurang paham dalam menyelesaikan soal yang berkaitan dengan sistem persamaan linear dua variabel.

4. Siswa kurang teliti dalam mengerjakan sistem persamaan linear dua variabel sehingga menjadi keliru dalam menyelesaikannya.

\section{Analisis Data II}

Berdasarkan hasil jawaban siswa yang diberikan pada tes hasil belajar II dapat dideskripsikan tingkat ketuntasan belajar dan penguasaan sebagai berikut:

1) Secara keseluruhan dari 31 orang siswa diperoleh 7 orang siswa $(22,58 \%)$ memiliki tingkat penguasaan sangat tinggi, 8 orang siswa $(25,80 \%)$ memiliki tingkat penguasaan tinggi, 12 orang siswa $(38,70 \%)$ memiliki tingkat penguasaan sedang, 4 orang siswa $(12,90 \%)$ memiliki tingkat penguasaan rendah dan tidak ada siswa yang memiliki tingkat penguasaan sangat rendah.

Hasil selengkapnya dapat dilihat dari tabel dibawah ini:

Tabel 5 Tingkat penguasaan siswa pada tes hasil belajar II

\begin{tabular}{|c|c|c|c|c|}
\hline No & $\begin{array}{l}\text { Persentase } \\
\text { Penguasaan }\end{array}$ & $\begin{array}{c}\text { Tingkat } \\
\text { Penguasaan }\end{array}$ & $\begin{array}{c}\text { Banyak } \\
\text { Siswa } \\
\end{array}$ & $\begin{array}{c}\text { Persentase } \\
\text { Jumlah Siswa }\end{array}$ \\
\hline 1 & $90 \%-100 \%$ & $\begin{array}{l}\text { Sangat } \\
\text { Tinggi }\end{array}$ & 7 & $22,58 \%$ \\
\hline 2 & $80 \%-89 \%$ & Tinggi & 8 & $25,80 \%$ \\
\hline 3 & $65 \%-79 \%$ & Sedang & 12 & $38,70 \%$ \\
\hline 4 & $55 \%-64 \%$ & Rendah & 4 & $12,90 \%$ \\
\hline 5 & $0 \%-54 \%$ & $\begin{array}{l}\text { Sangat } \\
\text { Rendah }\end{array}$ & 0 & $0 \%$ \\
\hline \multicolumn{3}{|c|}{ Jumlah } & 31 & $100 \%$ \\
\hline
\end{tabular}

2) Dari 31 orang siswa diperoleh 27 orang siswa $(87,10 \%)$ yang telah mencapai tingkat ketuntasan belajar ( $\geq 65 \%$ ), sedangkan 4 orang siswa $(12,90 \%)$ belum mencapai tingkat ketuntasan belajar (<65\%). Hasil selengkapnya dapat dilihat dari tabel dibawah ini.

Tabel 6. Data ketuntasan belajar siswa pada tes hasil belajar II

\begin{tabular}{|c|c|c|c|c|}
\hline No & $\begin{array}{l}\text { Persentase } \\
\text { Ketuntasan }\end{array}$ & $\begin{array}{c}\text { Tingkat } \\
\text { Ketuntasan }\end{array}$ & $\begin{array}{c}\text { Banyak } \\
\text { Siswa }\end{array}$ & $\begin{array}{c}\text { Persentase } \\
\text { Jumlah } \\
\text { Siswa }\end{array}$ \\
\hline 1 & $<65 \%$ & $\begin{array}{c}\text { Tidak } \\
\text { Tuntas }\end{array}$ & 4 & $12,90 \%$ \\
\hline 2 & $\geq 65 \%$ & Tuntas & 27 & $87,10 \%$ \\
\hline \multicolumn{3}{|c|}{ Jumlah } & 31 & $100 \%$ \\
\hline
\end{tabular}

Berdasarkan data hasil belajar II di atas dapat dilihat hasil belajar siswa juga meningkat. Hal ini dapat dilihat dari nilai rata-rata kelas pada tes hasil belajar I sebesar 68,70 meningkat menjadi 77,09 pada tes hasil belajar II dan syarat ketuntasan klasikal dengan 85\% keseluruhan siswa telah mencapai PHB $\geq 65 \%$ sudah dipenuhi. 


\section{Hasil Observasi II}

Berdasarkan data hasil observasi yang dilakukan dengan menerapkan model pembelajaran Numbered Head Together (NHT) diperoleh hasil observasi peneliti dan siswa. Hasil observasi untuk peneliti berdasarkan data observasi pada siklus II (Lampiran 36) diperoleh peningkatan terhadap proses pembelajaran. Hal ini dapat dilihat bahwa peneliti sudah baik dalam melaksanakan proses pembelajaran dan telah mampu meningkatkan pengelolaan pembelajaran. Sedangkan hasil observasi siswa pada siklus II (Lampiran 37) diperoleh bahwa siswa semakin berani mengemukakan pendapat, bertanya dan memberikan tanggapan terhadap kerja temannya dan sebahagian besar siswa bersemangat dan antusias dalam proses pembelajaran.

\section{Penyimpulan Data}

Hipotesis tindakan pada penelitian ini adalahpembelajaran kooperatif tipe numbered head together pada materi sistem persamaan linear dua variabel dapat meningkatkan hasil belajar siswa dan mengefektifkan kegiatan pembelajaran.

Hasil analisis data tes hasil belajar II dan observasi, hipotesis tindakan pada penelitian ini sudah tercapai, hal ini dapat dilihat dari tingkat ketuntasan klasikal yang diperoleh pada siklus II yakni 87,09\% sudah mencukupi syarat ketuntasan klasikal $\geq 85 \%$ siswa yang mencapai persentase penilaian $\geq 65$. Dan hasil observasi guru pada siklus II, diperoleh bahwa guru telah mampu meningkatkan pelaksanaan pembelajaran dengan menerapkan pembelajaran kooperatif tipe numbered head together. Hal ini terlihat dari hasil observasi pada siklus II yang mengalami peningkatan dari hasil observasi pada siklus I. Pelaksanaan proses belajar mengajar yang dilaksanakan guru pada siklus II ini juga sudah maksimal dengan rata-rata berada pada interval 2,6 - 3,5 termasuk dalam kategori baik. Berdasarkan hasil observasi siswa pada siklus II, nilai rata- rata yang diperoleh berada pada interval 2,6 - 3,5 termasuk dalam kategori baik sehingga diperoleh bahwa siswa telah mampu meningkatkan pelaksanaan kegiatan belajar yang mereka ikuti. Pada kegiatan siswa di siklus II ini, aktivitas yang dilakukan siswa pada setiap aspek kegiatan sudah dilaksanakan secara maksimal karena rata-rata skor tiap pertemuan termasuk dalam kategori baik. Waktu pembelajaran saat penelitian ini berlangsung juga tidak melebihi waktu pembelajaran seperti biasa.Dengan demikian berdasarkan hasil tes hasil belajar dan observasi pelaksanaan pembelajaran diperoleh bahwa pembelajaran kooperatif tipe numbered head together dapat meningkatkan hasil belajar sistem persamaan linear dua variabel pada siswa kelas VIII MTs Raudhatul Hasanah

\section{Pembahasan Hasil Penelitian}

Pelaksanaan pembelajaran berdasarkan hasil observasi untuk guru pada siklus I sebesar 2,83 meningkat pada siklus II menjadi 3,36. Lebih jelasnya dapat dilihat pada diagram di bawah ini :

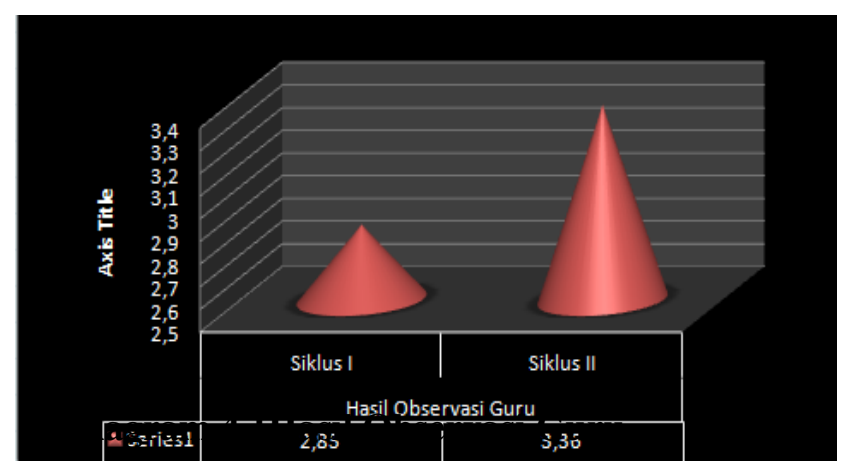

Diagram 1. Pelaksanaan Pembelajaran

Sedangkan pelaksanaan pembelajaran berdasarkan observasi untuk siswa pada siklus I sebesar 2,8 mengalami peningkatan pada siklus II sebesar 3,25. Hal tersebut dapat dilihat pada diagram dibawah ini : 


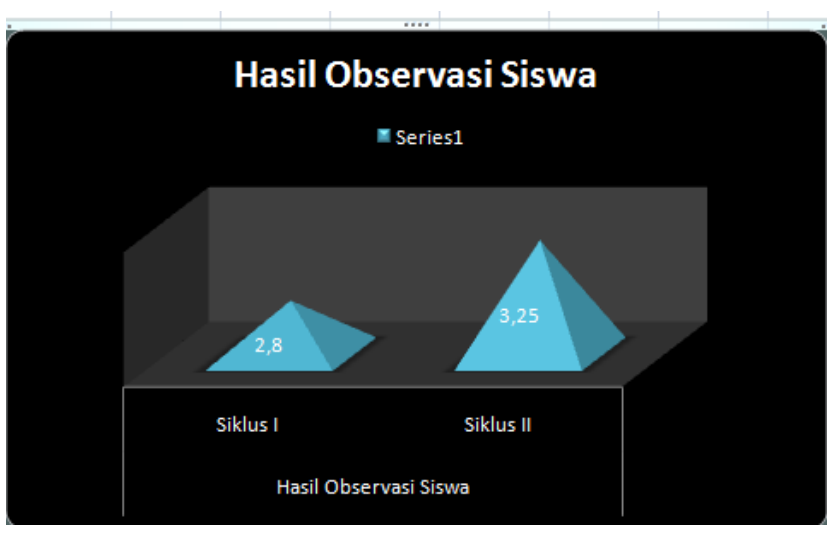

\section{Diagram 2. Hasil Observasi Siswa}

Berdasarkan hasil tes hasil belajar siswa pada siklus I dan siklus II, kemampuan siswa dalam menyelesaikan soal-soal SPLDV mengalami peningkatan. Hasil ini dapat dilihat dari :

1. Peningkatan nilai rata-rata kelas yang diperoleh siswa.Nilai rata-rata kelas pada tes hasil belajar siklus I sebesar 68,70 dan meningkat menjadi 77,09 pada siklus II sehingga diperoleh peningkatan rata-rata hasil belajar siswa sebesar 8,39. Lebih jelasnya dapat dilihat pada diagram di bawah ini :

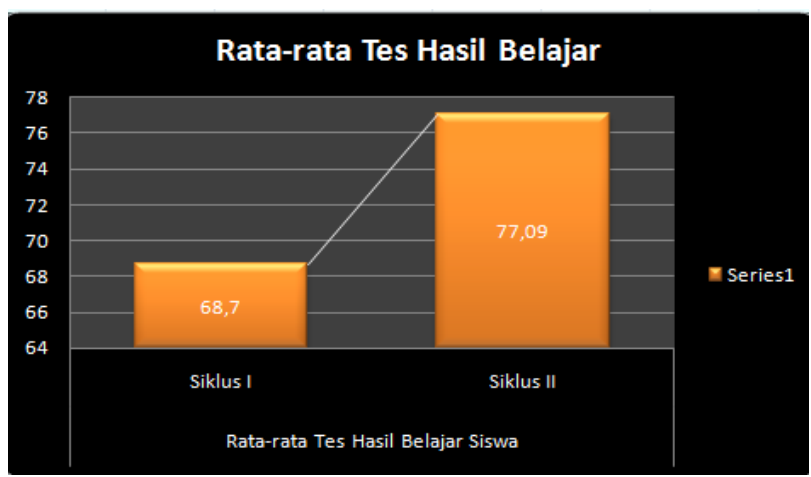

Diagram 3 Nilai Rata-rata Tes Hasil BelajarSiswa

Pada siklus I diperoleh 23 orang atau $74,19 \%$ siswa mencapai ketuntasan belajar, sedangkan pada siklus II diperoleh 27 orang atau $87,10 \%$ siswa mencapai ketuntasan belajar. Peningkatan jumlah siswa yang mencapai ketuntasan belajar adalah sebanyak 4 orang siswa atau $12,90 \%$.

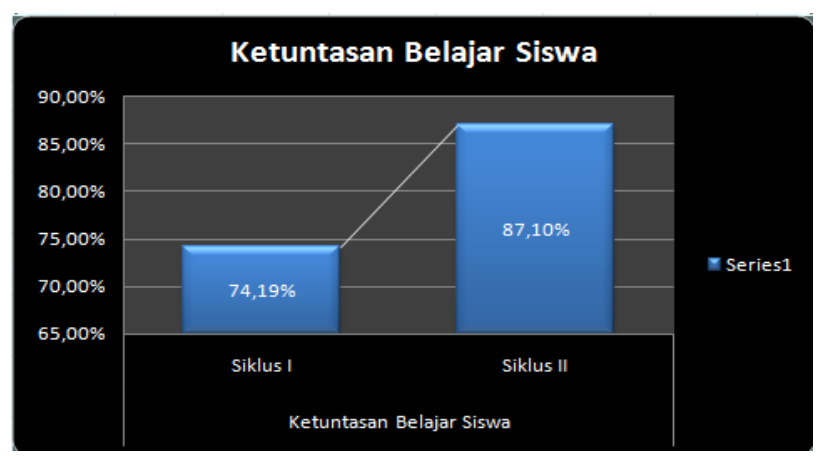

Diagram 4 Persentase Ketuntasan Belajar Siswa

Berdasarkan hasil penelitian yang diperoleh bahwa pembelajaran kooperatif tipe numbered head together dapat meningkatkan hasil belajar sistem persamaan linear dua variabel pada siswa kelas VIII- ${ }_{2}$ MTs Raudhatul Hasanah. Peningkatan hasil belajar siswa terlihat dari peningkatan pelaksanaan pembelajaran, peningkatan nilai rata-rata, peningkatan persentase ketuntasan belajar individu dan ketuntasan belajar klasikal. Dan kegiatan pembelajaran juga efektif dilihat dari hasil observasi pelaksanaan pembelajaran yang dilakukan sebanyak 2 siklus diperoleh bahwa pelaksanaan pembelajaran mengalami peningkatan dari siklus I ke siklus II. Pelaksanaan pembelajaran berdasarkan hasil observasi untuk guru pada siklus I sebesar 2,83 meningkat pada siklus II menjadi 3,36. Selanjutnya, pelaksanaan pembelajaran berdasarkan observasi untuk siswa pada siklus I sebesar 2,8 meningkat pada siklus II yaitu 3,25. Meningkatnya hasil observasi siswa dari siklus I ke siklus II menunjukkan bahwa pembelajaran menyenangkan dan memperoleh hasil yang baik. Berdasarkan hasil tes hasil belajar yang diberikan kepada siswa pada siklus I diperoleh nilai rata-rata sebesar 68,70 dan meningkat pada siklus II menjadi 77,09 sehingga diperoleh peningkatan rata-rata hasil belajar siswa 
sebesar 8,39. Selain itu, diperoleh peningkatan ketuntasan belajar sebanyak 4 orang $(12,90 \%)$, yaitu dari 23 orang siswa $(74,19 \%)$ pada siklus I meningkat menjadi 27 orang siswa $(87,09 \%)$ pada siklus II dan tingkat ketuntasan klasikal yang diperoleh pada siklus II yakni 87,09\% sudah mencukupi syarat ketuntasan klasikal yaitu $\geq 85 \%$ siswa yang mencapai tes hasil belajar $\geq 65$ dan waktu pembelajaran saat penelitian berlangsung tidak melebihi waktu pembelajaran seperti biasa.

\section{KESIMPULAN}

Berdasarkanhasil dan pembahasanpada bab IV dan penemuan selama pelaksanaan pembelajaran melalui model pembelajaran kooperatif tipe numbered head together, diperoleh beberapa kesimpulan yang merupakan jawaban atas pertanyaanpertanyaan yang diajukan dalam rumusan masalah. Kesimpulan tersebutadalah :

1. Hasil belajar siswa melalui penerapan pembelajaran kooperatif tipe numbered head together pada materi sistem persamaan linear dua variabel di kelas VIII MTs Raudhatul Hasanah meningkat.Hal ini dapat dilihat darites hasil belajar siswa yang telah diberikan pada siklus I mengalami peningkatan pada siklus II. Rata-rata skor tes hasil belajar siswa dan persentase ketuntasan belajar siswa juga mengalami peningkatan dari siklus I ke siklus II. Pada siklus I ketuntasan secara klasikal mengalami peningkatan sebesar $48,39 \%$ yaitu pada tes diagnostik 25,80\% menjadi 74,19\% dan nilai rata-rata kelas juga mengalami peningkatan sebesar 24,19 yaitu pada tes diagnostik 44,51 menjadi 68,70, tetapi belum memenuhi syarat ketuntasan klasikal $\geq 85 \%$. Pada siklus II hasil belajar siswa meningkat. Hal ini dapat dilihat dari tingkat ketuntasan secara klasikal mengalami peningkatan sebesar $12,91 \%$ yaitu pada siklus I $74,19 \%$ menjadi $87,10 \%$ pada siklus
II dan nilai rata-rata kelas juga mengalami peningkatan sebesar 8,39 yaitu pada siklus I 68,70 menjadi 77,09 pada siklus II. Dengan demikian hasil belajar siswa melalui penerapan pembelajaran kooperatif tipe numbered head together pada materi sistem persamaan linear dua variabel siswa kelas VIII MTs Raudhatul Hasanah sudah meningkat, maka penelitian tidak dilanjutkan ke siklus berikutnya.

2. Efektivitas pembelajaran ketika diterapkan pembelajaran kooperatif tipe numbered head together pada materi sistem persamaan linear dua variabel di kelas VIII MTs Raudhatul Hasanah memenuhi kriteria efektif. Hal ini dapat dilihat dari ketuntasan belajar yang diperoleh siswa telah mencapai ketuntasan individual $\geq 65$ dan ketuntasan klasikal $\geq 85 \%$, lembar observasi guru dan siswa yang telah diberikan mengalami peningkatan dari siklus I ke siklus II dan waktu pembelajaran saat penelitian berlangsung tidak melebihi waktu pembelajaran seperti biasa. Dengan demikian proses pembelajaran ketika diterapkan kooperatif numbered head together pada materi sistem persamaan linear dua peubah sudah efektiv.

\section{REFERENSI}

Abdurrahman, M., (2009), Pendidikan Bagi Anak Berkesulitan Belajar, Penerbit Rineka Cipta, Jakarta

Arikunto, S.,dkk., (2009), Penelitian

Tindakan Kelas, Penerbit Bumi

Aksara, Jakarta

Djamarah,S.,(1994) Prestasi Belajar dan Kompetensi Guru, Usaha Nasional, Surabaya 
Fakultas Matematika dan Ilmu Pengetahuan Alam Universitas Negeri Medan, (2010), Buku Pedoman Penulisan Skripsi dan Proposal Penelitian Kependidikan, FMIPA Unimed

Hudojo, H, (1988), Mengajar Belajar Matematika, Depdikbud, Dirjen Dikti, P2LPTK, Jakarta.

Masykur, dkk, (2008), Mathematical Intelligence : Cara Cerdas Melatih Otak dan Menanggulangi Kesulitan Belajar, Penerbit Ar-Ruzz Media, Jogjakarta

Muhli,A,(2011), (https://wicaksono.blogspot .com/2011/08/02/efektivitaspembelajaran/), (diakses 10 November 2014)

Muhammad, (2005), Pelatihan Terintegrasi Matematika Buku 3, Depdiknas, Jakarta

Nurhadi, (2004), Kurikulum 2004, Penerbit Grasindo, Jakarta.

Purwanto, (2011),Evaluasi Hasil Belajar, Penerbit Pustaka Pelajar, Yogyakarta.

Slameto, (2003),Belajar dan Faktor Faktor Yang Mempengaruhinya, Penerbit Rineka Cipta, Jakarta

Sudjana, (1992), Metoda Statistika, PenerbitTarsito, Bandung

Lundgren,(2009)

http://herdy07.wordpress.com/2009 104/22/modelpembelajarannht numbered-head-together/)

Sudjana. N., (2009), Penilaian Hasil Proses

Belajar Mengajar,

Rosdakarya,Bandung
Trianto, (2009), Mendesain Model Pembelajaran Inovatif Progresif: Konsep Landasan, Dan Implementasinya Pada Kurikulum Tingkat Satuan Pendidikan (KTSP), Penerbit Kencana Prenada Media Group, Jakarta

Usman, U. (2004), Menjadi Guru Profesional, Penerbit PT Remaja Rosdakarya, Bandung 